MUDRA: Journal of Finance and Accounting Volume 4, Issue 1, January-June 2017, pp. 144-158 doi: 10.17492/mudra.v4i01.9775

\title{
Working Capital Management and Profitability: A Study of Selected Auto Ancillary Companies in India
}

\author{
Bhaskar Biswas*
}

\begin{abstract}
The term working capital management refers to overall administration of all the current assets and current liabilities of the firm. Current ratio, day's sales outstanding, day's inventory, payables period, cash conversion cycle (CCC) are regarded as the measures of working capital management. An attempt has been made in the present study to evaluate the relation between working capital management and profitability of five selected auto ancillary companies in India viz, Bosch India, Motherson Sumi Systems Limited, Exide Industries Limited, Amara Raja Batteries and Wabco India Limited. Using Karl Pearson's simple and multiple correlation, and regression analysis, it is found that only in case of Amara Raja Batteries there is significant correlation between profitability and factors of working capital management.
\end{abstract}

Keywords: Working capital; Auto ancillary companies; Correlation; Profitability; Regression.

\subsection{Introduction}

Whatever be the size of a business, working capital is the life blood and controlling nerve centre of that business. Thus, working capital management is a very significant facet of financial management. Both excessive as well as inadequate working capital positions are dangerous from the firm's point of view. Excessive working capital implies idle funds which earn no profits for the firm while paucity of working capital not only impairs the firm's profitability but also results in business operation interruptions and inefficiencies. An overall control over working capital can ensure a proper functioning of the business operations.

\footnotetext{
*Assistant Professor, Raja Rammohun Roy Mahavidyalaya, Hooghly, West Bengal, India. (Email id: bhaskarbiswas2011@gmail.com)
} 
Working capital, in simple terms, is the amount of funds which a business firm uses to finance its day-to-day working on operations. It can also be regarded as that portion of the firm's total capital which is employed in short term operations or in current assets. Circulating capital means current assets of a company that are changed in the ordinary course of business from one form to another, for instance, from cash to inventories, or inventories to receivables. The term working capital management refers to the overall administration of all the current assets and current liabilities of the firm. It is concerned with the problems arising while managing the current assets, the current liabilities and the inter-relationships that exist between them. After discussing about working capital and its management now it will be valuable to focus on the past, present scenario of the Indian auto components industry.

The Indian auto components industry has experienced healthy growth over the last few years. Some of the factors attributable to this include: a buoyant end-user market, improved consumer sentiment and return of adequate liquidity in the financial system. The auto-components industry accounts for almost seven per cent of India's Gross Domestic Product (GDP) and employs as many as 19 million people, both directly and indirectly (source: Indian Brand Equity Foundation, July 2017). A stable government framework, increased purchasing power, large domestic market, and an ever increasing development in infrastructure have made India a favourable destination for investment. The Indian auto-components industry can be broadly classified into the organised and unorganised sectors. The organised sector caters to the Original Equipment Manufacturers (OEMs) and consists of high-value precision instruments while the unorganised sector comprises low-valued products and caters mostly to the aftermarket category. Over the last decade, the automotive components industry has scaled three times to US\$ 39 billion in 2015-16 while exports have grown even faster to US\$ 10.8 billion. This has been driven by strong growth in the domestic market and increasing globalisation (including exports) of several Indian suppliers. The Indian auto component industry is expected to grow by 8-10 per cent in FY 2017-18, based on higher localisation by Original Equipment Manufacturers (OEM), higher component content per vehicle, and rising exports from India, as per ICRA Limited. According to the Automotive Component Manufacturers Association of India (ACMA), the Indian auto-components industry is expected to register a turnover of US\$ 100 billion by 2020 backed by strong exports ranging between US\$ 80- US\$ 100 billion by 2026, from the current US\$11.2 billion. The Government of India's Automotive Mission Plan (AMP) 2006-2016 has come a long way in ensuring growth for the sector. It is expected that this sector's contribution to the GDP will reach US\$ 145 billion in 2016 due to the government's special focus on exports of small cars, multi-utility vehicles (MUVs), two 
and three-wheelers and auto components (source: Indian Brand Equity Foundation, July 2017). Separately, the deregulation of FDI in this sector has also helped foreign companies to make large investments in India. The Government of India's Automotive Mission Plan (AMP) 2016-2026 envisages creation of an additional 50 million jobs along with an ambitious target of increasing the value of the output of the sector to up to Rs $1,889,000$ crore (US\$ 282.65 billion) (source: Indian Brand Equity Foundation, July 2017).

\subsection{Review of literature}

Many researchers have studied working capital from different views and in different environments. This section reviews some of the studies that are interesting and useful for our research. Kithii (2008) tried to determine the empirical relationship between working capital management and firm profitability. The study used secondary data obtained from annual reports and financial statements of companies listed on the Nairobi Stock Exchange (NSE). A sample of 24 companies listed on the (NSE) for a period of six (6) years from 2001 - 2006, were studied to determine the effect of different variables of working capital management including average collection period, inventory turnover in day's, average payment period and cash conversion cycle on the gross operating profitability. Current ratio, size of the firm (measured in terms of natural logarithm of sales), fixed financial assets to total assets ratio and debt ratio were used as control variables. Pearson"s correlation and regression analysis (pooled least squares) were used for analysis. The results showed that there was a statistical significant negative relationship between variables of working capital management and the profitability of firms except for the average payment period which showed a positive relationship. Muhammad et al. (2011) conducted their study on textile industry, which is one of the oldest and at one time the fast developing industry in the large scale sector of Pakistan. The study is based on secondary data collected from listed firms in Karachi stock exchange for the period of 2001-2006 with an attempt to investigate relationship between profitability, and working capital management components. The effect of working capital management on profitability is tested using the panel data methodology. Based on correlation and regression analysis their findings showed that there is a strong positive relationship between profitability and cash, accounts receivable and, inventory while there is a negative relationship between profitability and accounts payable. This means that increase in cash, inventory and credit sales will lead to increase profitability of firm. 
Haresh (2012) observed a negative relationship between account receivables and corporate profitability and a positive relationship between accounts payable and profitability. The study focused exclusively on the firms listed in CNX Pharma index of National Stock Exchange of India. The data reported in this paper were collected for a period of 2005-06 to 2009-10 as a part of study designed to analyse profitability and working capital management from financial reports. Availability and comparison of data induced researcher to select Pharma index companies. Besides, the Index consists of ten companies holding majority of shares in the market, so the result can be generalised to other pharmaceutical companies also. The researcher concluded that the firms properly manage their cash, accounts receivables, accounts payables, and inventories in proper way, will ultimately increase profitability of these firms.

Salehi (2012) investigated the relationship between working capital changes and fixed assets with asset return of listed companies on Tehran Stock Exchange. In this research, in addition to working capital and fixed assets, the relationship between changes these variables and assets return had also been investigated. Statistical community of the study covers listed companies on Tehran Stock exchange during 20052010. Pearson correlation, Regression test and Kolmogorov-Smirnov test had been used to determining kind of relationship between dependent and independent variables, hypotheses test and evaluating normality of data respectively. The outcomes of the study suggested that there is a significant relationship between working capital changes and fixed assets with assets return statistically. Bose (2013) found that out of seven ratios (such as working capital turnover ratio, net current assets to total assets ratio, inventory turnover ratio, cash position ratio, current ratio), only cash position ratio has positive influence on return on total assets and the remaining has negative correlation with return on total assets and also found that return total assets is negatively associated with day's of working capital.

Makori and Jagongo (2013) found that the negative correlation between return on assets and the firms average collection period and cash conversion cycle while positive correlation with inventory holding period, accounts payment period. This paper analysed the effect of working capital management on firm's profitability in Kenya for the period 2003 to 2012. For this purpose, balanced panel data of five manufacturing and construction firms each which are listed on the Nairobi Securities Exchange (NSE) is used. The authors concluded that working capital management has a significant impact on profitability of the firms and play a key role in value creation for shareholders as large cash conversion cycle have negative impact on profitability of firms. Rehman and Anjum (2013) examined the impact that the running assets management on the profitability of Pakistan cement sector. Moreover, the study outlines the main factors that 
basically determine the working capital in the financials of Pakistan cement sector. To manage firm' sliquid assets which is working capital management and to reach a desire equilibrium level among profitability and risk, figures was collected from Annual Reports and sample consist of 10 Pakistani cement Companies listed at KSE from 20032008. The association between working capital management and profitability is examined with correlation; regression analysis the result proved that there is inverse and positive association between working capital management and profitability in cement industry of Pakistan.

Agha (2014) collected secondary data from Glaxo Smith Kline pharmaceutical company registered in Karachi stock exchange for the period of 1996-2011. The main purpose of this study was to empirically test the impact of working capital management on profitability. The author found that creditors' turnover ratio, debtors' turnover ratio and inventory turnover ratio have a positive significant impact on return on assets and there is no significant impact of current ratio on return on assets. Malik and Bukhari (2014) found that positive and insignificant relationship of average collection period and profitability while negative and insignificant relationship between profitability and average age of inventory and also found that the relationship between the average payment period and profitability is negative and significant. Moreover, operating cycle has positively insignificant while cash conversion cycle is positively significant relationship with profitability. The authors suggest that managers of these companies should spend more time to manage cash conversion cycle of their firms and make strategies of efficient management of working capital.

Oza (2015) observes that management of working capital is one of the most important and challenging aspect of the overall financial management. Only more effective and efficient management of working capital can ensure survival of a business enterprise. Working Capital Management is concerned with the management of the current assets and current liabilities and the interrelation that exists between them. The purpose of this study is to investigate the impact of working capital management on profitability, liquidity and risk on the Dabur India and Marico. The data has been collected from secondary sources and various statistical tools like average, Spearman's coefficient of correlation and accounting technique such as ratio are used in this study. The study reveals that there is a positive relationship between profitability and risk as well as negative relationship between liquidity and profitability.

Iqbal and Nasir (2015) investigated the relationship between working capital antecedents and profitability of the company. Seven variables are taken as proxy variable to measure working capital and its management. Population of the study is based on Karachi Stock Exchange listed companies. The sample of study is manufacturing sector 
of Pakistan. Thus, sample period contains on the ten years from (2005-2014). All variables have sound reliability and data is normally distributed. Therefore, correlation and regression analyses are applied. Hence, study revealed significant relationship of working capital management and profitability.

Samiloglu and Akgün (2016) examined the relationship link working capital management and performance such as profitability between accountant receivable period, accountant payable period and cash conversion cycle on Istanbul Stock Exchange (ISE) during the last ten years. This paper examined the relationship between working capital management and profitability. A sample of 120 Turkish manufacturing firms listed on ISE for a period 10 years from 2003 to 2012 was selected. Multiple linear regression models had been used to find out the relationship between working capital management and firm performance in the context of Turkey. The findings of this paper showed a significant and negative relationship between account receivable period and return on asset, return on equity, operating profit margin and net profit margin in the manufacturing industry. They expected that managers can create value for shareholders by reducing accountant receivable period, accountant payable period, cash conversion cycle.

\subsection{Objective of the Study}

Working capital is the life blood and controlling nerve centre of that business. Proper and efficient management of working capital leads to maximisation of profit and wealth of the organization. Inefficiency in dealing with working capital leads to the decrease chance of profitability and erosion of capital of the business. In the present study an attempt has been made to evaluate the close relationship between working capital management and profitability of the five selected auto ancillary companies in India viz, Bosch India, Motherson Sumi Systems Limited, Exide Industries Limited, Amara Raja Batteries and Wabco India Limited. More specifically, the objective of the study is to find out the relation between return on invested capital as a measure of profitability and current ratio, day's sales outstanding, day's inventory, payables period, cash conversion cycle (CCC) as the measures of working capital management.

\subsection{Research Methodology}

Five auto ancillary companies in India viz, Bosch India, Motherson sumi Systems Limited, Exide Industries Limited, Amara Raja Batteries and Wabco India Limited have been selected on the basis of their market capitalization more than Rs.10,000 crores and 
total assets amounting more than Rs.1,000 crores as on 15.05.2017. This study is based on secondary data only. The secondary data have been collected from www.moneycontrol.com and www.morningstar.in. Editing, classification and tabulation of the data collected from the above mentioned sources have been done as per the requirements of the study. For analysing the data simple mathematical tool like ratios, percentages etc. and statistical techniques like measures of central tendency, measures of dispersion, Karl Pearson's simple correlation and multiple correlation and regression analysis have been used.

\subsection{Analysis and Findings}

Table 1 shows the return on capital (ROC) invested of selected auto ancillary companies from March 2007 to March 2015. The average return on capital invested is highest for Motherson sumi Systems Limited (26.73\%) and lowest for Bosch India $(19.12 \%)$. The Standard deviation of return on capital invested is highest for Wabco India Limited (8.86) and lowest for Bosch India(4.04). The coefficient of variation of return on capital invested is highest for Wabco India Limited $(35.28 \%)$ and lowest for Exide Industries Limited (20.90).

Table 1: Return on Capital Invested in Selected Auto Ancillary Companies

\begin{tabular}{|l|c|c|c|c|c|}
\hline Year & $\begin{array}{l}\text { Bosch } \\
\text { India }\end{array}$ & $\begin{array}{l}\text { Motherson Sumi } \\
\text { Systems Limited }\end{array}$ & $\begin{array}{l}\text { Exide } \\
\text { Industries } \\
\text { Limited }\end{array}$ & $\begin{array}{l}\text { Amara Raja } \\
\text { Batteries }\end{array}$ & $\begin{array}{l}\text { Wabco } \\
\text { India } \\
\text { Limited }\end{array}$ \\
\hline 2007 & 26.46 & 38.57 & 9.98 & 22.06 & 30.20 \\
\hline 2008 & 22.4 & 38.24 & 17.97 & 16.99 & 37.17 \\
\hline 2009 & 18.23 & 26.73 & 17.83 & 13.79 & 15.94 \\
\hline 2010 & 22.96 & 23.99 & 26.94 & 25.8 & 29.36 \\
\hline 2011 & 25.44 & 31.95 & 25.79 & 21.67 & 38.34 \\
\hline 2012 & 18.6 & 14.92 & 17.62 & 25.8 & 33.16 \\
\hline 2013 & 14.91 & 21.37 & 18.72 & 27.11 & 22.21 \\
\hline 2014 & 15.36 & 29.15 & 16.49 & 28.33 & 16.75 \\
\hline 2015 & 15.07 & 27.45 & 16.84 & 25.51 & 14.94 \\
\hline Mean & 19.12 & 26.73 & 19.78 & 23.13 & 25.11 \\
\hline S.D & 4.04 & 6.99 & 4.14 & 5.21 & 8.86 \\
\hline $\begin{array}{l}\text { Coefficient } \\
\text { of Variation }\end{array}$ & 21.13 & 26.19 & 20.90 & 22.52 & 35.28 \\
\hline
\end{tabular}


Table 2 presents the current ratio of selected auto ancillary companies from March 2007 to March 2015. The average current ratio is highest for Wabco India Limited (2.76) and lowest for Motherson sumi Systems Limited (1.28).The Standard deviation of current ratio is highest for Wabco India Limited(1.09) and lowest for Exide Industries Limited (0.24).The coefficient of variation of current ratio is highest for Wabco India Limited(39.49\%) and lowest for Exide Industries Limited (13.87\%).

Table 2: Current Ratio in Selected Auto Ancillary Companies

\begin{tabular}{|l|c|c|c|c|c|}
\hline Year & $\begin{array}{l}\text { Bosch } \\
\text { India }\end{array}$ & $\begin{array}{l}\text { Motherson } \\
\text { sumi Systems } \\
\text { Limited }\end{array}$ & $\begin{array}{l}\text { Exide } \\
\text { Industries } \\
\text { Limited }\end{array}$ & $\begin{array}{l}\text { Amara Raja } \\
\text { Batteries }\end{array}$ & $\begin{array}{l}\text { Wabco } \\
\text { India } \\
\text { Limited }\end{array}$ \\
\hline 2007 & 1.87 & 1.77 & 1.48 & 2.67 & 1.06 \\
\hline 2008 & 2.34 & 1.7 & 1.59 & 3.2 & 1.07 \\
\hline 2009 & 2.09 & 1.2 & 1.65 & 2.85 & 1.81 \\
\hline 2010 & 2.01 & 1.32 & 1.53 & 1.98 & 1.85 \\
\hline 2011 & 2.02 & 1.42 & 1.67 & 2.13 & 2.71 \\
\hline 2012 & 3 & 1.02 & 2.26 & 2.27 & 3.29 \\
\hline 2013 & 2.71 & 0.98 & 1.86 & 2.18 & 4.11 \\
\hline 2014 & 2.64 & 1.5 & 1.61 & 2.05 & 3.78 \\
\hline 2015 & 2.11 & 1.1 & 1.64 & 2.39 & 3.46 \\
\hline Mean & 2.37 & 1.28 & 1.73 & 2.38 & 2.76 \\
\hline S.D & 0.37 & 0.25 & 0.24 & 0.43 & 1.09 \\
\hline $\begin{array}{l}\text { Coefficient of } \\
\text { Variation }\end{array}$ & 15.61 & 19.53 & 13.87 & 18.07 & 39.49 \\
\hline
\end{tabular}

Source: calculated by author

The day's sales outstanding of selected auto ancillary companies from March 2007 to March 2015 are shown in Table 3. The average day's sales outstanding is highest for Wabco India Limited (64.07) and lowest for Exide Industries Limited (20.99). The standard deviation of day's sales outstanding is highest for Motherson sumi Systems Limited(19.60) and lowest for Wabco India Limited (4.72).The coefficient of variation of day's sales outstanding is highest for Exide Industries Limited (51.88\%) and lowest for Wabco India Limited (7.37\%). High day's sales outstanding is not good from cash management perspective of the company and low day's sales outstanding is good from cash management perspective of the company.

Table 4 gives the day's inventory of selected auto ancillary companies from March 2007 to March 2015. The average day's inventory is highest for Amara Raja Batteries (3530.71) and lowest for Wabco India Limited (57.61). 
152 | MUDRA: Journal of Finance and Accounting, Volume 4, Issue 1, Jan-Jun 2017

Table 3: Day's Sales Outstanding in Selected Auto Ancillary Companies

\begin{tabular}{|l|c|c|c|c|c|}
\hline Year & $\begin{array}{l}\text { Bosch } \\
\text { India }\end{array}$ & $\begin{array}{l}\text { Motherson } \\
\text { sumi Systems } \\
\text { Limited }\end{array}$ & $\begin{array}{l}\text { Exide } \\
\text { Industries } \\
\text { Limited }\end{array}$ & $\begin{array}{l}\text { Amara Raja } \\
\text { Batteries }\end{array}$ & $\begin{array}{l}\text { Wabco } \\
\text { India } \\
\text { Limited }\end{array}$ \\
\hline 2007 & 47.54 & 45.45 & 33.09 & 70.94 & 60.05 \\
\hline 2008 & 51.66 & 51.25 & 28.75 & 62.74 & 51.76 \\
\hline 2009 & 49.29 & 95.26 & 29.88 & 60.15 & 62.57 \\
\hline 2010 & 35.9 & 48.87 & 12.19 & 56.06 & 62.26 \\
\hline 2011 & 38.11 & 38.49 & 0.00 & 55.88 & 63.64 \\
\hline 2012 & 41.52 & 49.01 & 14.62 & 48.2 & 57.37 \\
\hline 2013 & 43.34 & 42.92 & 29.18 & 43.18 & 65.62 \\
\hline 2014 & 41.56 & 37.06 & 27.46 & 44.29 & 69.23 \\
\hline 2015 & 46.12 & 32.99 & 25.81 & 43.63 & 71.84 \\
\hline Mean & 43.44 & 49.48 & 20.99 & 51.77 & 64.07 \\
\hline S.D & 5.36 & 19.60 & 10.89 & 7.88 & 4.72 \\
\hline $\begin{array}{l}\text { Coefficient } \\
\text { of Variation }\end{array}$ & 12.34 & 39.60 & 51.88 & 15.22 & 7.37 \\
\hline
\end{tabular}

Source: calculated by author

Table 4: Day's Inventory in Selected Auto Ancillary Companies

\begin{tabular}{|l|c|c|c|c|c|}
\hline Year & $\begin{array}{l}\text { Bosch } \\
\text { India }\end{array}$ & $\begin{array}{l}\text { Motherson } \\
\text { sumi Systems } \\
\text { Limited }\end{array}$ & $\begin{array}{l}\text { Exide } \\
\text { Industries } \\
\text { Limited }\end{array}$ & $\begin{array}{l}\text { Amara Raja } \\
\text { Batteries }\end{array}$ & $\begin{array}{l}\text { Wabco } \\
\text { India } \\
\text { Limited }\end{array}$ \\
\hline 2007 & 80.86 & 71.7 & 96.38 & 1489.31 & 35.50 \\
\hline 2008 & 78.03 & 78.19 & 94.7 & 888.57 & 36.98 \\
\hline 2009 & 79.88 & 106.07 & 99.16 & 7617.79 & 57.33 \\
\hline 2010 & 69 & 55.35 & 90.91 & 19457.33 & 51.04 \\
\hline 2011 & 81.83 & 59.78 & 104.97 & 77.15 & 46.43 \\
\hline 2012 & 88.53 & 59.74 & 108.74 & 59.6 & 55.99 \\
\hline 2013 & 85.51 & 52.76 & 109.43 & 47.02 & 89.81 \\
\hline 2014 & 85.33 & 54.62 & 123.12 & 49.55 & 71.53 \\
\hline 2015 & 78.66 & 57.28 & 101.43 & 48.67 & 53.23 \\
\hline Mean & 80.85 & 65.47 & 104.06 & 3530.71 & 57.61 \\
\hline S.D & 6.05 & 18.22 & 10.04 & 6945.68 & 16.52 \\
\hline $\begin{array}{l}\text { Coefficient } \\
\text { of Variation }\end{array}$ & 7.48 & 27.83 & 9.65 & 196.72 & 28.68 \\
\hline
\end{tabular}

Source: calculated by author 
The standard deviation is highest for Amara Raja Batteries (6945.68) and lowest for Bosch India (6.05). The coefficient of variation of day's inventory is highest for Amara Raja Batteries (196.72\%) and lowest for Bosch India (7.48\%). High day's inventory leads to long working capital cycle and vice versa.

Table 5 presents the payables period of selected auto ancillary companies from March 2007 to March 2015. The average payables period is highest for Amara Raja Batteries (2032.41) and lowest for Wabco India Limited (81.45).The Standard deviation of Payables period is highest for Amara Raja Batteries (4207.59) and lowest for Bosch India (5.81).The coefficient of variation of Payables period is highest for Amara Raja Batteries (207.02\%) and lowest for Bosch India (6.93\%). High Payables period good from cash management perspective but it hampers the goodwill of the company in market of components of production and vice versa.

Table 5: Payables Period in Selected Auto Ancillary Companies

\begin{tabular}{|l|c|c|c|c|c|}
\hline Year & $\begin{array}{l}\text { Bosch } \\
\text { India }\end{array}$ & $\begin{array}{l}\text { Motherson } \\
\text { sumi Systems } \\
\text { Limited }\end{array}$ & $\begin{array}{l}\text { Exide } \\
\text { Industries } \\
\text { Limited }\end{array}$ & $\begin{array}{l}\text { Amara Raja } \\
\text { Batteries }\end{array}$ & $\begin{array}{l}\text { Wabco } \\
\text { India } \\
\text { Limited }\end{array}$ \\
\hline 2007 & 88.44 & 41.22 & 68.77 & 1205.54 & 119.45 \\
\hline 2008 & 89.95 & 78.51 & 63.31 & 439.25 & 117.27 \\
\hline 2009 & 89.44 & 157.14 & 64.58 & 3744.03 & 112.66 \\
\hline 2010 & 81.56 & 91.59 & 57.73 & 11948.12 & 77.19 \\
\hline 2011 & 89.14 & 87.33 & 64.55 & 44.18 & 63.47 \\
\hline 2012 & 81.89 & 81.91 & 64.8 & 25.83 & 55.55 \\
\hline 2013 & 74.09 & 68.26 & 71.81 & 18.92 & 75.2 \\
\hline 2014 & 78.33 & 67.49 & 96.13 & 20.83 & 70.51 \\
\hline 2015 & 86.13 & 72.95 & 78.92 & 18.09 & 77.53 \\
\hline Mean & 83.82 & 88.14 & 70.23 & 2032.41 & 81.45 \\
\hline S.D & 5.81 & 29.17 & 12.23 & 4207.59 & 22.69 \\
\hline $\begin{array}{l}\text { Coefficient } \\
\text { of Variation }\end{array}$ & 6.93 & 33.10 & 17.41 & 207.02 & 27.85 \\
\hline
\end{tabular}

Source: calculated by author

Table 6 shows the cash conversion cycle of selected auto ancillary companies from March 2007 to March 2015. The average cash conversion cycle is highest for Amara Raja Batteries (1561.32) and lowest for Wabco India Limited (40.10).The Standard deviation of Cash conversion cycle is highest for Amara Raja Batteries (2799.74) and lowest for Bosch India (10.15).The coefficient of variation of Cash 
conversion cycle is highest for Amara Raja Batteries (179.32\%) and lowest for Bosch India $(25.08 \%)$. Low Cash conversion cycle good from cash management perspective and vice versa.

Table 6: Cash Conversion Cycle in Selected Auto Ancillary Companies

\begin{tabular}{|l|c|c|c|c|c|}
\hline Year & $\begin{array}{l}\text { Bosch } \\
\text { India }\end{array}$ & $\begin{array}{l}\text { Motherson } \\
\text { Sumi Systems } \\
\text { Limited }\end{array}$ & $\begin{array}{l}\text { Exide } \\
\text { Industries } \\
\text { Limited }\end{array}$ & $\begin{array}{l}\text { Amara Raja } \\
\text { Batteries }\end{array}$ & $\begin{array}{l}\text { Wabco } \\
\text { India } \\
\text { Limited }\end{array}$ \\
\hline 2007 & 39.95 & 75.93 & 60.69 & 354.71 & -25.00 \\
\hline 2008 & 39.74 & 50.92 & 60.14 & 512.06 & -28.53 \\
\hline 2009 & 39.74 & 44.2 & 64.46 & 3933.91 & 7.24 \\
\hline 2010 & 23.33 & 12.6 & 45.37 & 7655.27 & 36.11 \\
\hline 2011 & 30.8 & 10.95 & 0 & 88.85 & 46.59 \\
\hline 2012 & 48.17 & 26.84 & 58.56 & 81.98 & 57.81 \\
\hline 2013 & 54.77 & 27.42 & 66.8 & 71.28 & 80.24 \\
\hline 2014 & 48.55 & 24.19 & 54.44 & 73 & 70.25 \\
\hline 2015 & 38.66 & 17.33 & 54.32 & 74.22 & 47.54 \\
\hline Mean & 40.47 & 26.81 & 50.51 & 1561.32 & 40.10 \\
\hline S.D & 10.15 & 14.31 & 21.46 & 799.74 & 34.36 \\
\hline $\begin{array}{l}\text { Coefficient } \\
\text { of Variation }\end{array}$ & 25.08 & 53.37 & 42.49 & 179.32 & 85.69 \\
\hline Source: calculated by author & & & & \\
\hline
\end{tabular}

Tables 7-8 show the Pearson correlation analysis of profitability and factors of working capital management and multiple correlation and multiple regression of profitability on current ratio, day's sales outstanding, day's inventory, payables period and cash conversion cycle. Table 7 shows that the correlation coefficient between ROC and Current ratio of Bosch India and Exide Industries Limited are significant for $1 \%$ level of confidence. Correlation coefficient between ROC and Current ratio of Motherson sumi Systems Limited is significant for 5\% level of confidence and of Amara Raja Batteries is significant for $10 \%$ level of confidence. The negative correlation between ROC and day's sales outstanding of Bosch India is statistically significant at $1 \%$ level of confidence. The negative correlation between ROC and payables period of Exide Industries Limited is significant at $1 \%$ level of confidence. Table 8 shows that multiple correlation and multiple regression of profitability on current ratio, day's sales outstanding, day's inventory, payables period and cash conversion cycle. The computed multiple correlation co-efficient is tested with the help 
of ' $F$ ' test and computed multiple regression coefficient is tested with the help of ' $T$ ' test. In this analysis, current ratio, day's sales outstanding, day's inventory, payables period and cash conversion cycle are selected as independent variables and the ROC has been selected as dependent variable. The regression equation used in this study is as follows:

ROC $=\beta_{0}+\beta_{1}$ Current ratio $+\beta_{2}$ Day's sales outstanding $+\beta_{3}$ Day's inventory +

$\beta_{4}$ Payables period $+\beta_{5}$ Cash conversion cycle

The correlation coefficient between ROC and factors of working capital management i.e. current ratio, day's sales outstanding, day's inventory, payables period and cash conversion cycle of Amara Raja Batteries is statistically significant at 5\% level of confidence. However, the coefficient of regression of ROC and factors of working capital management of companies under consideration is not statistically significant.

Table 7: Pearson's Simple Correlation Analysis of Profitability and Factors of Working Capital Management

\begin{tabular}{|l|l|l|l|l|l|}
\hline & $\begin{array}{l}\text { Correlation } \\
\text { coefficient } \\
\text { between ROC } \\
\text { and Current } \\
\text { ratio }\end{array}$ & $\begin{array}{l}\text { Correlation } \\
\text { coefficient } \\
\text { between ROC } \\
\text { and Day's } \\
\text { sales } \\
\text { outstanding }\end{array}$ & $\begin{array}{l}\text { Correlation } \\
\text { coefficient } \\
\text { between ROC } \\
\text { and Day's } \\
\text { inventory }\end{array}$ & $\begin{array}{l}\text { Correlation } \\
\text { coefficient } \\
\text { between ROC } \\
\text { and } \\
\text { Payables period }\end{array}$ & $\begin{array}{l}\text { Correlation } \\
\text { coefficient } \\
\text { between ROC } \\
\text { and Cash } \\
\text { conversion } \\
\text { cycle }\end{array}$ \\
\hline $\begin{array}{l}\text { Bosch } \\
\text { India }\end{array}$ & $-0.60\left(\mathrm{t}=3.80^{*}\right)$ & $-0.09\left(\mathrm{t}=8.40^{*}\right)$ & $-0.09(\mathrm{t}=2.29)$ & $0.61(\mathrm{t}=1.19)$ & $-0.64(\mathrm{t}=0.00)$ \\
\hline $\begin{array}{l}\text { Motherson } \\
\text { Sumi } \\
\text { Systems } \\
\text { Limited }\end{array}$ & $0.90\left(\mathrm{t}=4.58^{* *}\right)$ & $-0.07(\mathrm{t}=0.01)$ & $0.30(\mathrm{t}=0.00)$ & $-0.26(\mathrm{t}=0.00)$ & $0.57(\mathrm{t}=0.50)$ \\
\hline $\begin{array}{l}\text { Exide } \\
\text { Industries } \\
\text { Limited }\end{array}$ & $0.01(\mathrm{t}=8.09 *)$ & $-0.80(\mathrm{t}=0.50)$ & $-0.17(\mathrm{t}=2.17)$ & $-0.41(\mathrm{t}=4.77 * *)$ & $-0.65(\mathrm{t}=0.00)$ \\
\hline $\begin{array}{l}\text { Amara } \\
\text { Raja } \\
\text { Batteries }\end{array}$ & $-.82\left(\mathrm{t}=2.40^{* * *}\right)$ & $-0.68(\mathrm{t}=0.00)$ & $-0.09(\mathrm{t}=0.17)$ & $-0.03(\mathrm{t}=0.18)$ & $-0.17(\mathrm{t}=0.15)$ \\
\hline $\begin{array}{l}\text { Wabco } \\
\text { India } \\
\text { Limited }\end{array}$ & $-0.43(\mathrm{t}=0.00)$ & $-0.74(\mathrm{t}=0.00)$ & $-0.54(\mathrm{t}=0.00)$ & $-0.11(\mathrm{t}=0.00)$ & $-0.31(\mathrm{t}=0.36)$ \\
\hline $\begin{array}{l}\text { Figures in bracket show [t] values } \\
* * * * * \text { and } * \text { indicate significance at } 10 \%, 5 \% \text { and } 1 \% \text { level } \\
\text { Table values } \\
\text { respectively } \mathrm{t} \text { with }(\mathrm{n}-2) \text { i.e } 3 \text { degrees of freedom at 10\%, 5\% }\end{array}$ &, $1 \%$ levels are 2.35, 3.18 and 5.84 \\
\hline
\end{tabular}

Source: calculated by author 
Table 8: Multiple Correlation and Multiple Regression of Profitability on and Factors of Working Capital Management

\begin{tabular}{|c|c|c|c|c|c|c|c|c|c|}
\hline Company & $\mathrm{R}$ & $\mathrm{R}^{2}$ & $\mathrm{~F}$ & $\beta_{0}$ value & $\begin{array}{l}\beta_{1} \\
\text { value }\end{array}$ & $\begin{array}{l}\beta_{2} \\
\text { value }\end{array}$ & $\begin{array}{l}\beta_{3} \\
\text { value }\end{array}$ & $\begin{array}{r}\beta_{4} \\
\text { value }\end{array}$ & $\begin{array}{c}\beta_{5} \\
\text { value }\end{array}$ \\
\hline Bosch India & 0.84 & 0.70 & 1.43 & $\begin{array}{l}0.63 \\
(-0.53)\end{array}$ & $\begin{array}{l}0.95 \\
(-0.06)\end{array}$ & $\begin{array}{l}0.32 \\
(1.19)\end{array}$ & $\begin{array}{l}0.32 \\
(1.19)\end{array}$ & $\begin{array}{l}0.32 \\
(-1.19)\end{array}$ & $\begin{array}{l}0.32 \\
(-1.19)\end{array}$ \\
\hline $\begin{array}{l}\text { Motherson } \\
\text { sumi Systems } \\
\text { Limited }\end{array}$ & 0.96 & 0.92 & 6.88 & $\begin{array}{l}0.52 \\
(-0.72)\end{array}$ & $\begin{array}{l}0.15 \\
(1.90)\end{array}$ & $\begin{array}{l}0.96 \\
(0.06)\end{array}$ & $\begin{array}{l}0.95 \\
(0.06)\end{array}$ & $\begin{array}{l}0.96 \\
(-0.06)\end{array}$ & $\begin{array}{l}0.96 \\
(-0.06)\end{array}$ \\
\hline $\begin{array}{l}\text { Exide } \\
\text { Industries } \\
\text { Limited }\end{array}$ & 0.90 & 0.81 & 2.54 & $\begin{array}{l}0.11 \\
(2.24)\end{array}$ & $\begin{array}{l}0.24 \\
(-1.44)\end{array}$ & $\begin{array}{l}0.12 \\
(-2.09)\end{array}$ & $\begin{array}{l}0.48 \\
(0.80)\end{array}$ & $\begin{array}{l}0.52 \\
(-0.72)\end{array}$ & $\begin{array}{l}0.29 \\
(1.29)\end{array}$ \\
\hline $\begin{array}{l}\text { Amara Raja } \\
\text { Batteries }\end{array}$ & 0.99 & 0.98 & \#28.97 & $\begin{array}{l}0.00 \\
\left(14.16^{*}\right)\end{array}$ & $\begin{array}{l}0.30 \\
(-1.23)\end{array}$ & $\begin{array}{l}0.19 \\
(-1.67)\end{array}$ & $\begin{array}{l}0.13 \\
(2.06)\end{array}$ & $\begin{array}{l}0.13 \\
(-2.04)\end{array}$ & $\begin{array}{l}0.13 \\
(-2.11)\end{array}$ \\
\hline $\begin{array}{l}\text { Wabco India } \\
\text { Limited }\end{array}$ & 0.92 & 0.84 & 2.17 & $\begin{array}{l}0.07 \\
(3.46 * *)\end{array}$ & $\begin{array}{l}0.88 \\
(-0.16)\end{array}$ & $\begin{array}{l}0.65 \\
(0.52)\end{array}$ & $\begin{array}{l}0.65 \\
(0.52)\end{array}$ & $\begin{array}{l}0.65 \\
(-0.52)\end{array}$ & $\begin{array}{l}0.65 \\
(-0.52)\end{array}$ \\
\hline \multicolumn{10}{|c|}{$\begin{array}{l}\text { Notes: } 1 \text {. t-stat in parantheses } \\
2 . *, * \text {, and } * * * \text { significant at } 10 \% \text { level, } 5 \% \text { level and } 1 \% \text { level } \\
\text { 3. \# Significant at } 5 \% \text { level of table value }(\mathrm{n}-\mathrm{k}-1) \text {, } \mathrm{k} \text { i.e }(3,5) \text { degree of freedom at } 5 \% \text { is } 9.01 \\
\text { 4. Table values of } \mathrm{t} \text { with }(\mathrm{n}-\mathrm{k}-1) \text { or } 3 \text { degree of freedom at } 10 \%, 5 \% \text { and } 1 \% \text { levels are } 2.35,3.18,5.84 \\
\text { respectively. }\end{array}$} \\
\hline
\end{tabular}

\subsection{Conclusion}

It may be concluded from the above discussion that the average return on capital invested is highest for Motherson sumi Systems Limited (26.73\%) and lowest for Bosch India (19.12\%). The average current ratio is highest for Wabco India Limited (2.76) and lowest for Motherson sumi Systems Limited (1.28). The average day's sale outstanding is highest for Wabco India Limited (64.07) and lowest for Exide Industries Limited (20.99). The average day's inventory is highest for Amara Raja Batteries (3530.71) and lowest for Wabco India Limited (57.61). The average Cash conversion cycle is highest for Amara Raja Batteries (1561.32) and lowest for Wabco India Limited (40.10). Correlation coefficient between ROC and Current ratio of Bosch India and Exide Industries Limited are significant for 1\% level of confidence . Correlation coefficient between ROC and Current ratio of Motherson sumi Systems Limited is significant for $5 \%$ level of confidence and of Amara Raja Batteries is significant for $10 \%$ level of confidence. The negative correlation between ROC and day's sales outstanding of Bosch 
India is statistically significant at $1 \%$ level of confidence. The negative correlation between ROC and payables period of Exide Industries Limited is significant at $1 \%$ level of confidence. However, coefficient of regression of ROC and factors of working capital management i.e current ratio, day's sales outstanding, day's inventory, payables period and cash conversion cycle of any companies under consideration is not statistically significant. But the correlation coefficient between ROC and factors of working capital management i.e current ratio, day's sales outstanding, day's inventory, payables period and cash conversion cycle of Amara Raja Batteries is statistically significant at 5\% level of confidence. The correlation coefficient between ROC and factors of working capital management i.e current ratio, day's sales outstanding, day's inventory, payables period and cash conversion cycle, of Bosch India, Motherson sumi Systems Limited, Exide Industries Limited and Wabco India Limited is not statistically significant.

\subsection{Limitations of the study}

The following are the limitations of the study that can be kept in mind and addressed in future research.

(i) The study is limited for a period 9 years from March 2007 to March 2015.

(ii) The study has taken into consideration five auto ancillary companies in India viz, Bosch India, Motherson sumi Systems Limited, Exide Industries Limited, Amara Raja Batteries and Wabco India Limited that have been selected on the basis of their market capitalisation being more than Rs.10,000 crores and total assets amounting more than Rs.1,000 crores as on 15.05.2017.

(iii) The study has used a limited number of mathematical and statistical parameters.

\section{References}

Agha, H. (2014). Impact of working capital management on profitability. European Scientific Journal, 10(1), 374-381.

Bose, B. (2013). The impact of working capital management practices on firm's profitability. International Journal of Applied Research and Studies, 2(6), 1-15.

Haresh, B. (2012). Working capital management and profitability: Evidence from IndiaAn empirical study. Ganpat University-Faculty of Management Studies Journal of Management and Research, 5(2), 1-16. 
Iqbal, S., \& Nasir, S. (2015). Working Capital Management Antecedants Impact on Firm Specific Factors: A Ten Year Review of Karachi Stock Exchange. International Letters of Social and Humanistic Sciences, 53, 107-111.

Kithii, J. N. (2008). The relationship between working capital management and profitability of listed companies in the Nairobi stock exchange. Unpublished MBA Project, University of Nairobi, Kenya.

Makori, D. M., \& Jagongo, A. (2013). Working capital management and firm profitability: Empirical evidence from manufacturing and construction firms listed on Nairobi securities exchange, Kenya. International Journal of Accounting and Taxation, 1(1), 1-14.

Malik, M. S., \& Bukhari, M. (2014). The impact of working capital management on corporate performance: A study of firms in cement, chemical and engineering sectors of Pakistan. Pakistan Journal of Commerce \& Social Sciences, 8(1), 134-148.

Muhammad, M., Jan, W. U. \& Ullah, K. (2011). Working capital management and profitability: An analysis of firms of textile industry of Pakistan. Journal of Management Sciences, 4(2), 155-167.

Oza, H. D. D. V. (2015). A comparative study of working capital management of Dabur India and Marico. Global Journal of Multidisciplinary Studies, 4(7), 1-6.

Rehman, M. U., \& Anjum, N. (2013). Determination of the impact of working capital management on profitability: an empirical study from the cement sector in Pakistan. Asian Economic and Financial Review, 3(3), 319-332.

Salehi, M. (2012). Examining Relationship between Working Capital Changes and Fixed Assets with Assets Return: Iranian Scenario. International Journal of Advances in Management and Economics, 1(1), 1-8.

Samiloglu, F., \& Akgün, A. İ. (2016). The Relationship between Working Capital Management and Profitability: Evidence from Turkey. Business and Economics Research Journal, 7(2), 1-14. 